\title{
Errors Made by Vocational School Students in Translating Analytical Exposition Text
}

\author{
Ayu Permatasari \\ Universitas Negeri Semarang, Indonesia \\ Email: ayu8permatasari@gmail.com \\ Issy Yuliasri \\ Universitas Negeri Semarang, Indonesia \\ Email: issy.yuliasri@gmail.com
}

\begin{abstract}
The research aims to describe the kinds of translation errors made by vocational school students in translating analytical exposition text from English into Indonesian. The method used in the research was descriptive qualitative. The subject of the research was the eleventh graders of Fashion Program of SMK Al Asror Semarang. An analytical exposition text consisting of 5 paragraphs (source texts) and all of its' translations in Indonesian (the target texts) were used in the research to find out the translation errors. Then the researchers classified them into 5 kinds of translation errors according to Vilar et al. (2006, p. 698). The results of the research revealed that there were 232 translation errors found in students' translation. There were translation errors in the form of incorrect word $(60.3 \%)$, punctuation $(26.3 \%)$, missing word $(6.0 \%)$, word order $(5.2 \%)$, and unknown words $(2.2 \%)$. In conclusion, the three most prominent error categories made by the students were incorrect word, punctuation, and missing word errors.
\end{abstract}

Keywords: Translation errors, students' translation, exposition text, Engish-Indonesian translation.

\section{INTRODUCTION}

Language is a tool to communicate or interact with people. The development of language walk together with the development of people's lives, it means language and people have a close relationship. Language is used by people in a society to express and receive thoughts, feelings, ideas, attitudes, and experiences. People must learn not only their mother tongue, which they have learned in their family or area where they live, but they also need to learn international languages used in international world such as English.

Indonesian students have already studied English since they are in Junior high schools (obligatory) or primary schools (optional, depending on the school policy) and they are expected to be able to communicate both spoken and written English upon completion of their Senior high school. In order to be able to use English, students should learn and understand four language skills and language elements. Language skills consist of listening, speaking, reading, and writing. Language elements consist of vocabulary, pronunciation, sound, meaning, and grammar.

In the case of vocational school, not all information has been covered in Indonesian yet. Vocational school students need to get more information from books written in English. That is why translation is needed. Catford (1965, p.20) defines translation as "the replacement of a textual maerial in one language (source language) by equivalent textual material in another language (target language)". Translation is very crucial in the process of exchannging information. "Without translation, prospective scientists will be left behind in the following the development of science, moreover if they lack the ability to read the foreign language text" (Widyamartaya, 1989).

Error that is made by learners are sometimes systematic (Ellis, 1997). Linguists revealed that learners' errors are systematic and that they reflect the stage of development that a learner has reached. So, one learner and another might have different error in certain condition but the source of error might be the same.

As the error is part of learning, Lightown and Spada (2000) have argued that when an error has occured frequently, it has been useful for teachers to bring the problem to the students' attention. "Identified types and causes of errors might help the students and the teachers to overcome students' common errors" (Parvin, 2019).

There are some previous studies concer- 
ning translation errors analysis. Krisetyawati (2010), Narulita (2016), Halimah (2018), connducted the researches about English-Indonesian translation errors in different contexts, Krisetyawati studied the students' errors in translating English noun phrases into Indonesian among fifth-semester students of the English Departement of Teacher Training and Education Faculty, Sebelas Maret University. There are four types errors occured; omission, misinformation, misordering, and addition errors. The highest number of errors is in omission errors (49.30\%). The other studies used genre texts as the object of study. For example Narulita (2018) conducted translation errors in narrative text. The most errors found were missing of substitute words, ommition, and wrong lexical choice. Other researchers, Silalahi, Rafli, and Rasyid (2018) also conducted a research on a scientific text as the object of study.

Napitupulu (2017) conducted a research on abstracts translated with Google Translate using five types of error classification namely lexicosemantic, tense, preposition, word order, distribution and use of verb group, and active and passive voice errors. While, Setiawan (2014) conducted a research on abstracts of Educational Administration Students of Post Graduate School of State University of Medan. Setiawan classified the type of errors into two types, namely grammatical errors and content errors. In grammatical error type, the use of the verb group took $58 \%$ and in the content error type, the presentation of different sense took $38 \%$. The dominant type of grammatical errors was caused by the confusion of verb groups in dealing with the English grammar systems. While, the dominant type of content errors was caused by the failure in choosing appropriate words. That is because of the lack of vocabulary mastery.

Hartono and Priyatmojo (2016) in their research used four samples of soft drink product labels as the texts to be translated. From the data analysis, they found many errors. The dominant errors found in translating those labels were mistranslation, addition, word choice, too free translated, too literal, word-for-word, grammar, punctuation, and spelling.Yastiawijaya (2018) conducted research about translation errors in English-Indonesian president's speech text produced by students of the sixth semester of English Education Program at STKIP Kie Raha Ternate. The research aimed to find what kinds of errors they made. The result showed that the students committed errors in omission $(97.3 \%)$, misinformation (1.8\%), and addition (0.9\%).

In conclusion, from the discussion of the previous studies above, the study which discusses students' translation errors from English-Indonesian according to Vilar et al. (2006:698) has not been done before. The errors is clasified into five big classes: Missing words, word order, incorrect words, unknown words, and punctuation errors. The classification can be seen in Figure 1.

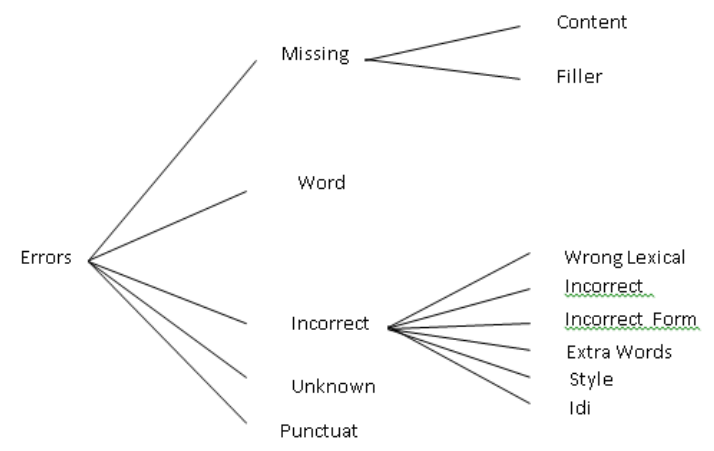

Figure 1. Classification of Translation Errors

For some people, translation is not an easy task to do. Also for vocational school students. Arono and Nadrah (2019) conducted a research about students' difficulties in translating English text and to find out the teacher's efforts to solve the problem. The result of the study shows that almost all the students still follow the form of the source language but they have tried to translate it into target language by modifying it. Some errors made were elliptical errors, idioms, and textual meaning. To solve the problem, the researcher recommended the teacher to conduct more varied methods, practices, and materials to motivate the students in translation class.

Therefore, the research problem of this study is (1) what kinds of translation errors are made by the $11^{\text {th }}$ graders Fashion Program of SMK Al Asror Semarang in translating exposition text. Based on the research problem above, this study would like to identify and describe the kinds of translation errors that made by the students in translating exposition text.

\section{METHODOLOGY}

This research employs descriptive qualitative method. This study is specific to text analysis which uses Context analysis approach. The subject of this research was the $11^{\text {th }}$ graders Fashion Program of SMK Al Asror Semarang. The object of this research was translation errors found in analytical exposition text made by them. The analysis was conducted in the following steps. First, reading the text carefully both in English and Indo- 
nesian. After the errors have been identified, they were classified into 5 categories of translation errors by Vilar et.al.(2006:698) as follows: Errors in the form of missing word, word order, incorrect word, unknown word, and punctuation.

\section{RESULTS AND DISCUSSION}

The data analyzed in this study were translation errors according to Vilar et.al. (2006: 698). There were 232 errors found in the students' translation in eleventh graders Fashion Program of SMK Al Asror Semarang academic year 2019/2020. After analyzing the data, the researchers found out that the students made all kinds of errors in their translations. There were 232 errors covering missing words (content and filler word), word order, incorrect words (wrong lexical choice, incorrect disambiguation, incorrect form, and extra words), unknown words, and punctuation. The data can be seen in table 1 .

The three most prominent error categories made by the students are errors in the form of incorrect word, punctuation, and missing word. Incorrect word becomes the highest category of tanslation errors which occured $(60.3 \%)$ of the errors found in the analysis. It was followed by punctuation $(26.3 \%)$ and missing word (6.0\%).

There are examples of the data analysis based on the findings on the students' translation errors.

\section{Missing word}

There were two kinds of missing words found i.e. content word and filler word. Content word concerns with missing words which are important to express the meaning of the sentence. Filler word concerns with missing words which are merely needed to form a grammatically correct sentence.

\section{Content word}

From the data, there were 9 errors found in students' translation.

Example:

SL: In Australia there are three levels of governments, the federal government, state governments and local governments.

TL: di australia masih banyak 3 pemerintahan, pemerintahan pusat, $k b$ pemerintah dan lokal pemerintah.

BT: In Australia there are still 3 governments, federal government, government $\mathrm{kb}$ and government local.

Based on the example above, the student made errors called punctuation, missing word, unknown word, and words order. Errors in the form of missing word occured because the student did not translate the important word that is supposed to be written to show the meaning "tingkatan"(levels) to make the sentence equivalent with the SL. From the explanation above, that sample can be categorized as missing word errors especially error in content word.

\section{Filler word}

From the data, there were 5 errors found in students' translation.

Example:

SL: They look after things like collecting rubbish, otherwise everyone would have diseases.

TL: mereka setelah melihat berbagai hal mengumpulkan sampah, jika tidak tiap orang akan mempunyai penyakit.

BT: they after seeing many things collecting rubbish, otherwise everyone would have disease.

Based on the example above, there found

Table 1. Frequency of Errors

\begin{tabular}{|c|c|c|c|c|c|c|}
\hline No. & Kinds of Error & & Errors' frequency & $\%$ & Total & $\%$ \\
\hline \multirow{2}{*}{1.} & \multirow{2}{*}{ Missing word } & Content word & 9 & $3.9 \%$ & \multirow{2}{*}{14} & \multirow{2}{*}{$6.0 \%$} \\
\hline & & Filler word & 5 & $2.2 \%$ & & \\
\hline 2. & Word order & & 12 & $5.2 \%$ & 12 & $5.2 \%$ \\
\hline \multirow{6}{*}{3.} & \multirow{6}{*}{$\begin{array}{l}\text { Incorrect } \\
\text { word }\end{array}$} & Wrong lexical choice & 75 & $32.3 \%$ & \multirow{6}{*}{140} & \multirow{6}{*}{$60.3 \%$} \\
\hline & & Incorrect disambiguation & 17 & $7.3 \%$ & & \\
\hline & & Incorrect form & 35 & $15.1 \%$ & & \\
\hline & & Extra word & 13 & $5.6 \%$ & & \\
\hline & & Style & 0 & $0 \%$ & & \\
\hline & & Idiom & 0 & $0 \%$ & & \\
\hline 4. & \multicolumn{2}{|l|}{ Unknown Word } & 5 & $2.2 \%$ & 5 & $2.2 \%$ \\
\hline 5. & \multirow{2}{*}{\multicolumn{2}{|c|}{ Punctuation }} & 61 & $26.3 \%$ & 61 & $26.3 \%$ \\
\hline Tota & & & & & 232 & $100 \%$ \\
\hline
\end{tabular}


errors in the form of punctuation, wrong lexical choice, missing word, and incorrect form. To make the sentence above grammatically correct, there should be a conjunction "seperti" (like) which is supposed to be placed in the target language. Conjunction is used to give connection between sentences. The student should add a conjunction "seperti"(like) between"things" and "collecting" for a better translation. From the explanation above, that sample can be categorized as missing word error especially errors in filler word.

\section{Word Order}

Word order errors showed that the error directs to the wrong structure of the sentence. Twelve errors were found in students' translation. Example:

SL: In Australia there are three levels of governments, the federal government, state governments and local governments.

TL: di australia masih banyak 3 tingkat pemerintahan, pemerintahan pusat, $k b$ pemerintah dan lokal pemerintah.

BT: in australia still many 3 levels of governments, federal government, $\mathrm{kb}$ government and local government.

Based on the example above, lokal pemerintah should be replaced by pemerintah lokal because Indonesian noun phrase follows Head-Modifier pattern. There is different structure in head and modifier between source text and target text. In English, the structure of noun phrase has a dominant position of modifier-head, whereas in Indonesian, it has position of head-modifier. Because local is a modifier and government is a head, so the structure should be "pemerintah lokal". The error in writing the structure of noun phrase above indicates a word order error.

\section{Incorrect Word}

According to Vilar et al. (2006:698) classification of errors, there are 6 kinds of incorrect words in students' translation. There were for wrong lexical choice, incorrect disambiguation, incorrect form, extra words, style, and idiom errors. This research only occured four errors; wrong lexical choice, incorrect disambiguation, incorrect form, and extra words.

\section{Wrong Lexical Choice}

Wrong lexical choice is the most cause of errors that happened in the students' translation. There were 75 errors $(32.3 \%)$ found in the students' translation.

Example:
SL: Similarly, the state government looks after the middle sized things.

TL: Dengan cara yang sama, setelah melihat pemerintah negara yang kedua.

BT: Similarly, after seeing the second state government.

Based on the example above, there was error in the form of incorrect word specially in the form of wrong lexical choice. "look after" and "middle sized things". "Look after" is a phrasal verb which means mengurus (taking care of) but the student translate the phrase word for word into setelah melihat (after seeing). Totally, there were 39 errors found in students' translation for translating a phrasal verb "look after" in the text. Then "middle sized things" translated into "yang kedua" (the second of). From the explanation above, that sample can be categorized as incorrect words errors especially errors in wrong lexical choice.

\section{Incorrect Disambiguation}

The sum of incorrect disambiguation errors were $28(12.0 \%)$ that are found in the students' translation worksheet.

Example:

SL: They keep the economy in order and look after things like defense.

TL: mereka menyimpan ekonomi di dalam pesanan dan melihat tentang berbagai hal sama seperti pembelaan.

BT: they save the economy in order and see about things same as defense.

Based on the example above, there was error in the form of incorrect disambiguation found in the target language. The translation here causes incorrect disambiguation and give confusion for the reader. Keep was translated into menyimpan (save), in order was translated into di dalam pesanan (in errand), look after was translated into melihat tentang (look about), and defense was translated into pembelaan (plea). The disambiguation was caused by some wrong lexical choices that happened in the text.

\section{Incorrect Form}

This kind of error refers to the wrong grammatical form for example the use of tenses, subject verb agreement, and the wrong word form. For example, it is supposed to use noun but the adjective form is used. Incorrect forms occure 35 times $(15.1 \%)$ in the students' translation.

Example:

SL: For examples they look after law and order, preventing things like vandalism in schools.

TL: Untuk contoh mereka selanjutnya melihat per- 
aturan dan perintah, mencegah berbagai hal suka merusak di sekolah.

BT: For example they next seeing law and command, preventing things like vandalism in school.

Based on the example above, there found errors in the form of incorrect form. The word "like" is not appropriate in the word form. Like in TL was translated into a verb suka (love). Suka means to find something pleasant or satisfactory. Here, like is as a conjunction that means seperti (as). The errors in writing the form of part of speech of the word above indicates error in the form of incorrect form.

\section{Extra Word}

Extra words refer to words that are not important to be present in the translation. There are 13 times (5.6\%) extra words errors found in the students' work.

Example:

SL: All of these levels of government are necessary.

TL: Semua 3 tingkat pemerintah sangat penting.

BT: All of these 3 levels of government are very important.

The meaning of the underlined word on the target language "sangat" is not mentioned in the source language. The student wrote additional word which is not written on the source language. Therefore, the meaning in the target language is different from the source language. To be "are" on the source language does not necessarily translate as "sangat"(very). In conclusion, the word "sangat" (very) belongs to error in the form of extra word.

\section{Unknown Word}

Unknown word refers to the word that was detected and considered unknown because it does not exist in the dictionary. Such words are found 5 times $(2.2 \%)$ errors in students' translation.

Example:

SL: They look after things like collecting rubbish, otherwise everyone would have diseases.

TL: Mereka suka melihat kolek sampah, kebalikannya semua orang akan mempunyai penyakit.

BT: They like seeing collect rubbish, otherwise everyone would have disease.

The word "collecting" was translated into "kolek". There is no such word as "kolek" in Indonesian. So, it is classified into unknown word because the readers do not know the meanings.

\section{Punctuation}

Punctuation errors occure 61 times (26.3\%) in students' translation. In this study, the errors found were capital letter, full stop, comma, and quotation mark.

Example:

SL: In Australia there are three levels of governments, the federal government, state governments and local governments.

TL: Di australia disana ada tiga tingkat pemerintahan. pemerintahan pusat itu, keadaan pemerintah dan lokal pemerintah.

BT: In australia there are three levels of government, that federal government, situation governments and local governments.

The example above, shows error in the form of wrong lexical choice, word order, and punctuation. Wrong lexical choice occures in word "state" translated into "keadaan" (situation), words order occure in "lokal pemerintah" should be replaced by "pemerintah lokal" because Indonesian noun phrase follows Head-Modifier pattern, and errors in the form of pnctuation occures in capitalization; name of a nation (Australia) should be written in a capital letter.

\section{CONCLUSION}

The results of the study show that incorrect word errors are the most prominent. Wrong lexical choice, incorrect form, and incorrect disambiguation are the three most common incorrect word errors. This implies that the students have grammatical and vocabulary problems in understanding English as their foreign language.

Each student made around 26 until 43 translation errors from the analytical exposition text consisting of 5 paragraphs and 10 sentences. It means that the errors made are quite significant. So, for the teachers, it is recommended to highlight grammar and vocabulary in the teaching-learning process and to give chance the students to do more translation practice.

\section{REFERENCES}

Arono \& Nadrah. (2019). Students' difficulties in translating English text. Journal of Applied Linguistics and Literature. 4(1).

Catford, J. (1978). A linguistic theory of translation. Oxford : Oxford University Press.

Ellis, Rod. (1997). Second Lanuage Acquisition. Oxford: Oxford University Press.

Halimah. (2018). Error analysis in English-Indonesian machine translate. International Seminar on Education and Development of Asia. 29-36.

Hartono, R., \& Priyatmojo, A. (2016). Tanslation errors of soft drink product labels from Indonesian into Engish. The International Seminar Prasasti III (pp. 659-664). Surakarta: Linguistics 
Doctoral Program of Sebelas Maret University. Krisetyawati, B. (2019, march 13). An error analysis on the translation of English noun phrases into Indonesian of the fifth semester students of the English Department of Teacher Training and Education Faculty, Sebelas Maret University in the Academic Year 2009/2010.

Lightbown, P.M. and Spada, N. (2000). How Languages are Learned. Oxford: Oxford University Press.

Napitulu, S. (2017). Analyzing Indonesian-English abstracts translation in view of translation errors b Google Translate. International Journal of English Language and Linguistics Research,5 (2), 15-23.

Narulita, S. (2016). Error analysis on student's narrative text in translation class of English Department of Kutai Kartanegara University. Jurnal Intelegensia, 1(1).

Parvin, S. (2019). Error analysis of the written production of te undergraduates of English literature. The 7th ELTLT International Conference ( $p p$. 213224). Semarang: Faculty of Languages and
Arts, State University of Semarang.

Setiawan, Y. (2013). English translation errors in abstract of Educational Administration Students. Unpublished Master's Thesis, UNIMED.

Silalahi, M., Rafli, Z., \& Rasyid, Y. (2018). The analysis of errors in translation of scientific text from English to Indonesian Language. Journal of Education Teaching and Learning. 3(1).

Vilar et al. (2007). Error analysis and statistical machine translation output. Universidad Politecnica de Madrid.

Widyamartaya, A. (1987), Kreatif mengarang. Yogyakarta: Kanisus.

Wnag, X. (2009). Exploring the negative transfer on English learning. Asian Social Science, 138143.

Yastiawijaya, R. (2018). Translation errors in EnglishIndonesian president's speech text produced by students of the sixth semester of English Education Program at STKIP Kie Raha Ternate. Journal of Linguistics, Literature, and Language Education, 1(1). 